\title{
Men's Tears Also Matter: A Study on the Patriarchal Oppression of Men in Literature
}

\author{
Waruni Tennakoon \\ Department of English, Buddhist and Pali University of Sri Lanka, Homagama, Sri Lanka \\ Email: waruni@bpu.ac.lk
}

How to cite this paper: Tennakoon, W. (2021) Men's Tears Also Matter: A Study on the Patriarchal Oppression of Men in Literature. Open Access Library Journal, 8: e7693.

https://doi.org/10.4236/oalib.1107693

Received: June 24, 2021

Accepted: August 1, 2021

Published: August 4, 2021

Copyright () 2021 by author(s) and Open Access Library Inc.

This work is licensed under the Creative

Commons Attribution International

License (CC BY 4.0).

http://creativecommons.org/licenses/by/4.0/

(c) (i) Open Access

\begin{abstract}
The present study focuses on the popularly established idea that women are almost always oppressed under the patriarchal system while all men enjoy its benefits. Concerning some selected literature, the study argues the possibilities of "certain" men being the victims of patriarchy, carrying both manly and womanly qualities (according to patriarchal interpretations) to be more successful in their roles as men. Victims of patriarchy in this context refer to those who do not satisfy the gender stereotypical characteristics drawn by the patriarchal system and whose voices are unheard in society. The sample of the present study which falls victim to their effort to act upon the gender expectations of their culture includes Okonkwo in the novel "Things Fall Apart" by Chinua Achebe, Macbeth in the drama "Macbeth" by William Shakespeare, and Viscount Gontran-Joseph de Signoles in the short story, "A Coward" by Guy de Maupassant. The analysis of the protagonists' failure of these literary works raises the awareness of the "forgotten sex" in literature and obviously in society. Likewise, the present paper seeks to analyse whether a fine balance between the qualities of men and women would define successful personalities for men, which would help eliminate their ego-centrism that keeps women under their rule of thumb. The necessity of rejecting patriarchy which provides satisfaction to neither men nor women and replacing it with a system where men may freely respond to various circumstances of life without being the "outcasts" of their societies is also highlighted in the conclusion of the research.
\end{abstract}

\section{Subject Areas}

Literature, Gender Studies

\section{Keywords}

Patriarchal System, Men, Women, Victims, Gender Stereotypes, Forgotten Sex 


\section{Introduction}

Gender stereotypes set forth by the patriarchal societies, have confirmed a code of beahviour for everyone in the society giving rise to gender inequality. Even if everyone is not affected by it in the same way, not everyone is free from its effects. The popular "gender conspiracy" theory that condemns all men as the oppressors and women as the oppressed (Millet 1977) [1] is challenged by some modern researchers asserting that men also fall victim to patriarchy in various ways (Idriss 2021, Clemence \& Jairos 2011). The present paper attempts to prove through literature how men, who are ill-qualified to meet the patriarchal standards, also fall victim to it other than women. It also questions whether a balance of the qualities of men and women would make up a "happier man" calling for the necessity of immediate rejection of age-old patriarchal set-up in the society which satisfies neither men nor women. The research is thus based on the hypothesis that freedom for men is possible with the social acceptance that a man's success lies with his possession of both the qualities of men and women. The contempt directed towards such men who exhibit these qualities has given rise to a third type of gender, the third sex, which is often ignored and forgotten. Okonkwo in the novel "Things Fall Apart" by Chinua Achebe, Macbeth in the drama "Macbeth" by William Shakespeare, and Viscount Gontran-Joseph de Signoles in the short story, "A Coward" by Guy de Maupassant is shown in this paper to represent this group of the forgotten sex in literature as they fell victim to the very same patriarchal system of whose expectations these characters were forced to upheld. The present paper falls under qualitative research discipline, and with the analysis of relevant literature, it contributes to gender studies as well as English literary research.

\section{Literature Review}

\section{Gender Identity in Patriarchy}

In almost every society, adherence to one's gender from childhood is considered crucial as it directs many aspects of everyone's lives, including education, relationships, occupations, etc. A young girl who climbs on trees and stays firm in child disputes is contemptuously considered "boy-like" while boys who cry and are afraid of darkness or frogs are often laughed at as "woman-like". Discussing these gender stereotypes promoted by the patriarchy, Newsome (Wardy $2014 \mathrm{p}$. xii) [2] says:

Our young girls, right out of the womb, are sold the notion that their value lies in their youth, their beauty, and their sexuality, while their brothers and male peers are taught early on that boys are our natural-born leaders and that domination, control, and aggression can be utilized to preserve the status quo.

Talking about the shaping of kids' minds to grow up with gender stereotypes set by the society, Wardy (ibid p. 4) [2] lists out the themes she found on various 
kiddies' items as follows:

Girls = baby dolls, baby care items, princesses (all Disney), sexy fashion dolls whose faces and bodies look like they have been surgically altered, beauty/makeup toys, play cooking and baking sets, animal care toys, and crafts.

Boys $=$ monsters, action or war figures, superheroes, rescue or action vehicles, building blocks and kits, sports and outdoor toys, guns and weapons, scientific experiment kits, and dinosaurs.

The adult ideas on raising kids in a patriarchal setup can clearly be understood by looking at the toys defined for the kids, and boys never enjoy the happiness of cuddling the dolls. In contrast, girls' interest in toy-vehicles and toy soldiers are condemned to be ridiculed. Society has never accepted a place for gender neutrality and,

"...if a boy was interested in cooking, he would have to go into the 'girl aisle' and choose something dipped in pink. If a girl wanted an action figure or a Lego set, she very clearly had to walk into the 'boy aisle' to get it. Likewise, in the practical situation, patriarchal society measures women's value and power in terms of their sexuality rather than their capabilities and capacities" (ibid p. 5).

Lerner (1986) [3] suggests patriarchy be an institutionalized form of male dominance over women and children, both within the family and society. In the same way, feminist writers such as Firestone (1977) [4] have seen patriarchal structure as the arena of women's subordination and the architecture of discriminatory gender roles. Likewise, men are uniquely identified by Metcalf (1989) as the members of the oppressing class and,

“dismisses male writers' attempts to participate in the production of a true literature of liberation of the oppressed... [because] male African novelists, accomplished as they may be... are... members of the oppressing class" (as qtd in Clemence \& Jairos 2011 p. 61).

Strong and De Vault (1989) [5] state that being male is not an easy task as they have to adhere to the social demands expected by the patriarchal society to be successful in the eyes of the society. The maleness is widely and over time has been equated with aggression, competitiveness, lack of fear, analytical reasoning, anger, fear of failure, competition, strength, etc. In contrast, femininity is equated to submissiveness, weakness, irrationality, emotionality, complaining, and dependence (May, 2001) [6]. As Strong et al. (1983 p. 52) [5], point out "A man may wish to give up his role as the family provider and become a "househusband", but there are pressures against such decisions". There seems to be a growing awareness among scholars that even men should struggle for freedom:

... men's movement may eventually develop... because the traditional male role is dysfunctional. Yet men rarely express the pain that lies beneath the 
surface of their lives because it is not considered manly to express emotions (Foreman, 1982 as qtd in Clemence \& Jairos 2011 p. 62).

Similarly, being supported by the growing awareness of the oppression against men in the patriarchal social system, this research attempts to find out the example characters of such from English literature representing genres of novels, short stories, and dramas and see possession of which qualities would free men from the patriarchal oppression.

\section{Discussion}

Things Fall Apart by Chinua Achebe narrates the tragic fall of Okonkwo and the Igbo community in Africa. Okonkwo, one of the most respected and influential leaders of this community, has won his life with a lot of hard work, and he has brought fame to his village through his bravery and courage. The causes for his tragic fall are his fear of weakness and dislike to change. In his attempts to cover up certain emotional aspects inherent to his character, he pretends to be someone he is not. Okonkwo violently responds to the changes in his culture that require negotiation and adaptation, and as a result, he kills one of the British messengers. None of his clansmen takes his side, and Okonkwo, devastated by his attempts to protect his culture from the British colonists, commits suicide in the end.

Three witches greet Macbeth, the protagonist of the tragic play Macbeth by William Shakespeare, with the future titles he will soon be received. Even if Macbeth is primarily encouraged by these prophecies, he decides to give up his intention to kill Duncan for many reasons. Lady Macbeth, blackmails Macbeth teasing him of his manliness, and Macbeth ultimately kills the King proving that he is as manly as his society defines a man: courageous, brave, and not-yielding to emotions. The murder of the king leads to many other murders that he commits out of paranoia. Macbeth and Lady Macbeth are devastated by guilt and paranoia and ultimately kill themselves.

Maupassant's $A$ Coward narrates a story of a man named Viscount GontranJoseph de Signoles who lives up to the gender standards of the society as a courageous, honourable and brave gentleman. When he notices that one of the ladies he invited has been uncomfortable because of a continuous stare that she received from another man, Signole promptly acts according to what he thinks a man is expected to do. Thus, as a brave man, he challenges Lamil, the other man, to a duel and his acceptance of that and the weapon of his choice becoming the pistol make Signole doubt his capability to fight with him. The fear of losing his dignity and discredit owned as a man if the duel is lost makes him further lose his confidence. Maupassant is sarcastic when he narrates how Signole gains confidence when he drinks a decanter of rum, and when the effect of alcohol is lessened, his fear returns. This incident points out several cases reported almost every day of drunken men who use their manly power to subjugate innocent women. Signole effectively mirrors those who are struggling to maintain the 
image of the "man" they have to keep to satisfy the social norms of men. Finally, he decides to commit suicide as he decides death is better than having to live in humiliation with wounded pride for losing the battle. Ultimately, Signole paid the price for living his whole life as someone he is truly not.

The novel "Things Fall Apart" by Chinua Achebe is set in Umuofia and Mbanta. At the outset of the novel, Achebe clears out that men should be "warlike" in Umuofia, and those who are not so, like Unoka and Nwoye are culturally looked down upon. The most significant character trait of Okonkwo in "Things Fall Apart" is his attempt to celebrate manliness while condemning any quality associated with femininity in line with the gender stereotypes. To Okonkwo, his father, Unoka, lazy and unheroic, is synonymous with femininity, so he is determined to reject what his father represented. As an attempt to do so, Okonkwo embraces all the opposite ideals of his father, adopting a personality that is violent, hardworking, wealthy, brave, and not-inclined-to-emotions. On the contrary, Okonkwo betrays these qualities with his love for Ikemefuna and Ezinma. Still, in his struggle to submerge any natural feeling that he considers "soft" and thus unmanly and the stubbornness to maintain the values of his culture with no change and criticism, he loses his worth in the changing society.

In Chapter 7, both Nwoye and Ikemefuna have to move to their lodgings from women's quarters to Okonkwo's obi as they are now no mere boys. All the stories related to these grown-up boys are male-dominated tales of violence and bloodshed. Their desire to be in the women's obi, listening to wonderful stories of beauty, nature, etc., was not counted, and thus they are forced to be in the male quarters. Okonkwo has a prolonging fear of Nwoye to be like his father, an "agbala": a "woman" because his father was a failure in his eyes, having neither a barn nor titles. Unoka's artistic skills and the sensitivity were pejoratively dismissed in the Umofian society, as those were considered to equate to women. In the killing of Ikemefuna, the men who did not take part in the journey to kill him were mocked and laughed at as women. Okonkwo, thus with the fear of being called an agbala, joins this journey and kills Ikemefuna. This is the social pressure that Okonkwo and most men in the novel have been suffering; the fear to be called a woman. Even though Okonkwo suffers a lot before and after killing Ikemefuna; his adopted son, in cold blood and disowning Nwoye for not adhering to the patriarchal values saying, "I will only have a son who is a man" (Chapter 17), Okonkwo becomes a willing victim of the patriarchal oppression. Achebe writes, even if Okonkwo out-showed anger and cruelty,

"down in his heart [he]...was not a cruel man. But his whole life was dominated by fear, the fear of failure and of weakness... It was not external but lay deep within himself" (Chapter 2).

Okonkwo's love for Ikemefuna was evident in the novel, as he showed masculinity, fearlessness, and strength. Achebe, makes him kill this beloved innocent child out of his fear of being called a woman; “...dazed with fear, Okonkwo drew his matchet and cut him down. He was afraid of being thought weak" (Chapter 
7). This clearly shows how hard Okonkwo and many other men of the patriarchal system were oppressed for meeting its demands. The rule of the Ibo culture was for the men to control their women, and those who were unable to control their women at home were considered to be weak or not men, believing it to be a despicable insult for the state of being a man.

No matter how prosperous a man was, if he was unable to rule his women and his children (and especially his women) he was not really a man (Chapter 7).

Obeirika, who serves as a foil for Okonkwo was a person of receptive nature and thus willing to accept changes to the age-old Igbo values. Achebe seems to be approving the character of Obeirika to be a balanced personality who was also a victim of patriarchy. Just as Okonkwo, Obeirika was also a victim as despite his willingness to go away from certain values of his culture, he could not do so with the fear of being condemned by society. He showed his disapproval of Okonkwo in taking part in the murder of Ikemefuna and expressed his willingness to go away from the rigid standards of masculinity in his society. In many instances of the novel, Achebe has revealed the true, yet hidden emotions of Okonkwo. His true emotions are always hidden as those would make him a weak personality as those emotions are always associated with women. In Chapter 4, Achebe writes:

Even Okonkwo himself became very fond of the boy-inwardly of course. Okonkwo never showed any emotion openly, unless it be the emotion of anger. To show affection was assign of weakness; the only thing worth demonstrating was strength.

Again in the same chapter, Achebe says that Okonkwo was "inwardly" repentant about breaking peace during the "Week of Peace" but, "he was not the man to go about telling his neighbours that he was in error" because he was so self-centered that such an act would diminish his status as a man. The emotional side of Okonkwo is also evident in Chapter 12 when he felt so much for Ezinma and his wife Ekwefi:

It was only his fourth trip that he found Ekwefi, and by then he had become gravely worried (Chapter 12).

Okonkwo's deliberate hiding of his authentic emotions is once again shown in Chapter 8 after he kills Ikemefuna. After spending sleepless nights, without eating, and only drinking palm-wine from morning till night, Okonkwo questioned himself, "When did you become a shivering old woman... Okonkwo, you have become a woman indeed".

Thus, it is evident that the fear of showing qualities that have been stereotyped to be feminine has made men feel so oppressed in society. Achebe seems to suggest a fine balance between these two types of qualities meant for men and women to relieve men of their oppression from society.

This fear for the society for failure to be a "man" is depicted well in "A Co- 
ward", a short story by Guy de Maupassant. Here the protagonist, Viscount Gontran-Joseph de Signoles, who was called by the society, "Handsome Signoles" was such a man who possessed almost every quality a perfect "man" would possess:

He had a good figure and a good carriage, a sufficient flow of words to pass for wit, a certain natural grace, an air of nobility and pride, a gallant moustache and an eloquent eye, attributes which women like.

Moreover, he was a fine swordsman and a "still finer shot with the pistol" and a courageous young man. With all these qualifications of a successful "man", he has grown so ego-centric that he was led by the feeling that he was undefeatable. The scene where a man was staring at one of his female friends brings out gender politics in the drama identifying Signoles to be a perfect figure for the patriarchal expectations, whereas the husband of the woman at whom the man was staring was taken to be weak. Signoles' ego is clearly depicted in him boxing the man for merely staring at his female friend which turns out to be the story's turning point. When his masculinity is questioned in terms of an invitation for a dual, he shockingly discovers that no strength is to be found in him as he is even scared of the thought of fighting. This fear springs out of nothing else but his fear to be a failure.

... he thought of the disgrace, of the whispers at the club, of the laughter in drawing-rooms, of the contempt of women, of the allusions in the papers, of the insults which cowards would fling at him... If, when face to face with the other man, he did not show a proper gallantry and calm, he would be lost forever. He would be sullied, branded with a mark of infamy, hounded out of society.

Just as it was for Okonkwo, Signoles also could not face to bear up the humiliation of defeat as he was so self-centered as a brave man and thus kills himself. Signoles, too lacks the courage to be humble and forgiving as they are qualities that would disqualify him as a man in his society. Just as it was for Okonkwo, Signoles also thinks taking off his life to be grander than to be slandered unmanly.

William Shakespeare's "Macbeth" is a drama that shows the masculine hero as a victim of patriarchy. Many times in the play, Shakespeare has let the role reversal of gender takes place making the audience ponder over the possible "in-between" gender which is taken as the forgotten sex in this research paper. In want of adhering to patriarchal expectations of being a man, Macbeth; a man, "too full of the milk of the human kindness" falls victim to countless murders. Lady Macbeth compels Macbeth, who vehemently rejects killing Duncan by emotionally blackmailing him, reducing him to possess "womanly fear". When Macbeth is ready to forget the promised kingship as he is unwilling to kill virtuous Duncan, Lady Macbeth rebukes him saying he is not a "man" but a coward like the poor cat in the adage. Macbeth, who is another victim of the pa- 
triarchal system, pleads with his wife attempting to reassert his manhood, refusing the belittling remarks of Lady Macbeth:

Prithee, peace:

I dare do all that may become a man;

Who dares do more is none (ACT 1, Scene VII).

In reply, Lady Macbeth plays with the word "man", saying to commit a crime is manly, as it displays his bravery, thus arousing the sensitivity of Macbeth to the patriarchal demands. Just as Okonkwo volunteered to kill his "son" as an indication of his courage, Lady Macbeth rebukes Macbeth saying she dares to dash the brains out of a newborn baby who is sucking milk from her, interpreting such kind of bravery to be manly. Macbeth once again becomes sandwiched between the patriarchal demands and his true will of sensitivity when Banquo's ghost appalls Macbeth. With this fear, Lady Macbeth further reduces him to be an old lady narrating stories told to her by her grandmother at winter's fire. The question of masculinity arises again with Macbeth's denial to be brave, ignoring Banquo's ghost. Thus, Macbeth fails to satisfy the patriarchal demands for a man as he says that this ghost makes him tremble to the core like a baby girl.

What man dare, I dare:

Approach thou like the rugged Russian bear;

The arm'd rhinoceros, or the Hyrcan tiger;

Take any shape but that, and my firm nerves.

Shall never tremble: or be alive again;

And dare me to the desert with thy sword;

If trembling I inhabit then, protest me.

The baby of a girl (Act III scene IV).

Likewise, Shakespeare has painted the character of Macbeth with some exception to the patriarchal stereotype of a man. Thus, just as Okonkwo and Signoles, we see Macbeth has also been a victim of the patriarchy which changes him from a valiant warrior to a bloodhound. Shakespeare brings out the question of manhood further in the scene where Macduff is revealed of the massacre of his family. Malcolm advises him to, "Dispute it like a man" and Macduff answers:

I shall do so.

But I must also feel it as a man (Act IV, Scene III).

Similarly, Shakespeare has tried to change the perception of gender in "Macbeth", suggesting certain alterations to the masculine character traits defined in the patriarchal system. Here Shakespeare suggests a balance between the so-called qualities of women and men to be a man of free will. As Macduff says, a man can be a man and also mourn the brutal murder of his beloveds. Likewise, Shakespeare has tried to change the perception of gender in "Macbeth" suggesting certain alterations to the masculine character traits defined in the patriarchal system.

\section{Conclusions}

Society has inevitably stereotyped the characteristics of men and women, and 
these stereotypes have been passed from generation to generation. These notions have been deeply rooted within almost all the people in the society, and perceiving men and women out of these boxes have been almost impossible. Thus, the gender studies should be extended to include the "forgotten sex" apart from the widely spoken first and the second sexes. (Even if the phrase "forgotten sex" has been used in terms of men who do not strictly adhere to the patriarchal expectations in the current research, the same can be applied to women of the same nature).

The present paper, looking at selected literature, a novel, short story, and drama, tries to raise the awareness that both men and women share specific characteristics and men cannot always be the oppressors of patriarchy but they are also victimized by that system which is meant to be supportive to them. From the examples of the aforesaid works of literature, it is clear that in life it does not matter whether a person is male or female, but what matters the most is how a person can be herself or himself in various situations of their lives without being prisoners of any system. With this finding, the research also suggests the fact that the awareness of society, in general, should be raised to the oppression patriarchy brings to both men and women. The perceptions of society should be changed in terms of the values of men and women. Therefore, men should not be painted to be personalities whose hearts are never melted in pain, sufferings of others. The same rule applies to women also. The character of Lady Macbeth, who tries to impose male characteristics on herself, is presented as a failure at the end. Thus a necessity has sprung up to build up a system where both men and women are valued for being who they are. The freedom of men and women despite their gender should equally be valued and the characteristics of them should be valued as unique to their personalities. No one should be a prisoner of their gender. Thus, the present research concludes that the forgotten sex in literature should be highlighted in literary criticisms to advance a gender movement for the freedom of both sexes.

\section{Conflicts of Interest}

The author declares no conflicts of interest.

\section{References}

[1] Millet, K. (1977) Sexual Politics. Illinois UP, Chicago.

[2] Wardy, M. (2014) Redefining Girly: How Parents Can Fight the Stereotyping and Sexualizing of Girlhood. Chicago Review Press, Chicago.

[3] Lerner, G. (1986) The Creation of Patriarchy, Routledge, London.

[4] Firestone, S. (1979) The Dialectic of Sex: The Case for Feminist Revolution, Women's Press, London.

[5] Strong, B. and De Vault, C. (1989) The Marriage and Family Experience. West Publishing Company, New York.

[6] May, T. (2001) Situating Social Theory. Open University Press, Buckingham. 